\title{
TYPES OF ASSESSMENT TESTS USED IN THE TEACHING AND LEARNING OF ENGLISH LANGUAGE IN AWENDO SUB-COUNTY, KENYA
}

\author{
Otiep Augustine Odundo ${ }^{1 *}$, Prof. Florence Y. Odera ${ }^{2}$, Dr. Karen A. Oyiengo ${ }^{3}$
}

\author{
*Corresponding Author: -
}

\begin{abstract}
: -
Continuous Assessment is a very important process in any educational program and it is also one of the key steps in curriculum implementation in primary schools in Kenya. The government of Kenya adopted continuous assessment to help in gauging learners' performance with a view of making necessary adjustments to help improve teaching and learning process. The instructional methodologies used in the teaching and learning process are meant to provide attainment of certain goals in education, however, it can be said that continuous assessment has not been given the attention it requires because learning outcome has continued to be poor, especially in English language in class seven which is a precandidate class for national examination. The data on performance of learners in English language as a subject is available in Awendo Sub-County. The purpose of this study was to identify the types of assessment used in teaching and learning of English language in class seven in public primary schools in Awendo Sub-County. Descriptive survey research was used in conducting this study. The study was conducted in Awendo sub-county, Migori County. The study targeted 71 head teachers, 71 class seven teachers of English, 5 Curriculum Support Officers and 2354 pupils, giving a total population of 2501. Saturated sampling was used to sample head teachers, teachers of English and Curriculum Support Officers. However, on the side of the pupils, the researcher used simple random sampling to get the sample size of 235 which is $10 \%$ of pupils' population. Therefore, the total sample size was 382. To establish the validity and reliability of research instruments, piloting was done in two schools that would not be included in the study. Data collection was done using questionnaires for class seven teachers of English and class seven pupils and interview schedules for head teachers and C.S.Os. Data analysis was done through descriptive statistics and results presented in the form of tables, graphs and descriptive form. The findings of this study may be useful to the Ministry of Education officials who are the policy makers, the Teachers Service Commission and other researchers. It may be useful for them to help in undertaking further research in the teaching and assessment of English language in the country. The research findings were as follows: the study revealed that formative assessment was commonly used. The study recommended that the government should employ more teachers to reduce teacher shortages in schools, teachers should use a variety of instructional methods and different types of continuous assessment tests in the teaching and learning. The study also recommended that further research should be done in other counties.
\end{abstract}

Keywords: Assessment, teaching, learning, teachers, pupils

\section{(a) $(\$)$}




\section{INTRODUCTION}

Traditionally, the evaluation of learner's progress was based on tests and examinations which focused only on the cognitive aspects of a learner while other facets were ignored, (Jacobs and Gawe, 2017). However, Fraser, (2016) noted that traditional methods of learner assessment was advantageous in that promotion of learners was based on past continuous assessment tests. This did not favour pupils who might have missed some exam, probably due to unavoidable circumstances like sickness. Secondly, teaching was teacher-centred because the teacher was the major source of information. Pupils were mere listeners in the teaching and learning process. This was characterized with chalk and talk kind of teaching, that is, lecture method. It made learning theoretical and boring. At the same time, progress was difficult to determine because the only yard stick to measure acquisition of knowledge, skills and attitudes was by testing on what has been learnt. For example; there were no midterm tests for learners, only to sit for end term tests. Thus, learners did not get a chance to realize their strengths and weaknesses so as to improve on them. This made Webb and Briars, (2010), to argue that assessment must be an interaction between the teacher and the students, with the teacher continually seeking to understand what a student can do and how a student is able to do it.

Yoloye, (2008), further pointed out that continuous assessment is only a part of the field of educational evaluation. He further argued that continuous assessment is a method of evaluating the progress and achievement of students in educational institutions. In addition, Yoloye, (2008), noted that educationists, during the early nineties, voiced their disapproval of the traditional methods of assessment such as assessment in relation to age, for example, learners would be allowed in school not because of their ability, but how old or big in body size, some assessments were based on assumptions depending on where the learner came from. However, Frazer, (2016), observed that traditional methods of assessment were also good and had various advantages such as promotion of learners that was based and confined to a specific number of tests and examinations during the year. This did not go well with learners who might have, for one reason or another, physically or emotionally unstable due to calamity during examination time. At the same time, Frazer, (2016), noted that learners were not always aware of their progress because examinations were not given quite often to allow teachers to identify areas of weaknesses to decide on the best methodology. Frazer, (2016), also reported that comparison of results to be aware of learners' progress was difficult due to longer periods between one test and another, for example, termly tests and yearly tests (summative). Consequently, Graeme and Naidoo, (2004), felt that continuous assessment tests or school based assessment should test the total growth of pupils including the nonscholastic areas and, therefore, should be built into teaching and learning process. This kind of assessment required change, therefore, continuous assessment was introduced to address this demand for change and is considered by psychologists and educators as new trend that not only places emphasis on the intellectual ability of the learners, but also takes into consideration a learner's skills, attitudes, knowledge and values.

There are various types of continuous assessment tests teachers administer to students in schools. These types of continuous assessment tests can be in the form of English composition which the pupils need to master. The primary concern of assessment of composition skills is the content of students' writing. They describe the skills of writing as a variety of interrelated graphic skills that include composition which is the ability to generate ideas and express them in an acceptable grammar and spelling which is the ability to use letters to construct words in accordance to accepted usage, and handwriting which is the use of graphic mark to produce legible messages. Continuous assessment tests also include oral reading. Rodger, (2003), states that a teacher can set a number of tests or parts of tests to assess the accuracy and fluency of a students' ability to read aloud. According to Salvia and Yssel 1998, different oral reading tests record different behavior as errors in oral reading. These include omission of a word or groups of words, insertion of a word, and avoiding punctuations. Teachers should use patterns of assessment that seems to attain required outcomes and to guard against others (Aggarwal, 2001). This means that the pattern of assessment used should lead to the targeted behavior from the learners in relation to knowledge, skills and attitudes.

Herman \& Baker, (2005), suggest that schools should use the 'big ideas' or key principles of each subject area to organize the specific learning expectations described by state students. It is on this basis that Herman \& Baker, (2005), saw the importance of using various types of continuous assessment to help limit monotony in assessment, hence effective evaluation, aimed at improving performance.

American Association for the Advancement of Science, (2016), categorized the purpose of assessment into internal and external purposes. The internal purposes for assessment include conveying to students expectations about what is important to learn, providing information to students and parents about students' progress, helping students to judge their own learning, guiding and improving instruction, classifying and selecting students. The external purpose was to inform the education donors including parents, education departments and ministry about what happens in schools. The report also indicated that assessments were given most frequently in Mathematics, Reading, Science and Writing, hence an indication that formative assessment was being used. In Japan, School of East Asian Studies, the University sets out principles to promote assessment that is fair, valid and reliable. In addition, institution- wide assessments are defined at every level of progression through programs of study. According to the University of Sheffield Western Bank, (2017), the institution-wide criteria have been structured in such a way as to indicate a student's intellectual progression and development at each stage of the learning experience.

Cumming, (2009), pointed out three common problems in classroom-based assessment, namely, teachers' training in assessment, assessment of professional or curriculum standards in their teaching and assessment of their teacher trainees' learning.

In Ghana, the government officially introduced a system of summative assessment in 1987, (Quansah, 2005). This mandated the completion of four class tests, a total of 33 major assessment activities per subject. Continuous assessment marks are added to the end of term subjects' examination, counting for $70 \%$ of the total grade. 
The Kenya government then adopted the idea of Continuous Assessment Tests in 1985, to assess learners' success. This was meant to reduce the importance that was attached to summative assessment. Continuous Assessment is very important in curriculum implementation, but teachers seem not to be using different types of continuous assessment tests, in relation to instructional methodologies.

\section{Types of Continuous Assessment Tests}

There are different types of assessment tests administered to pupils by teachers.

They include:

Diagnostic Assessment Assessment of student's skills and knowledge upon entry to the program provides a baseline against which to assess progress, (Mugenda and Mugenda, 2003). They further state that diagnostic assessment happens at the start of a new phase of education like starting a new unit.

Teachers use diagnostic testing information to guide what and how they teach. They are sets of written questions (multiple choice or short answer), that assesses a learner's current knowledge base or current views on a topic or issue to be studied in the course. The goal is to get a snapshot of where students currently stand intellectually, emotionally or ideologicallyallowing the instructor to make sound instructional choices as to how to teach new course content and what teaching approach to use to improve learners' performance.

\section{Formative Assessment}

Formative assessment can involve providing feedback following an assessment, but more importantly, this feedback is delivered during instruction, allowing instructors to identify student misunderstandings and help them correct their errors, (Shute, 2008).

Kothari, (2013), states that formative assessment is a wide variety of methods teachers use to conduct in-process evaluation of students' comprehension, learning needs and academic progress during a lesson or course. Sarosdy, (2004), also argue that formative assessment has many purposes which are used to monitor students' progress during the course and to check how much they have learned of what they should have learned. It can be carried out as a form of informal tests and quizzes and it is the basis for feedback to the students.

\section{Norm-Referenced Assessment}

This is assessment that is based on comparing the relative performances of students, either by comparing the performances of individual students within the group being tested or comparing their performances with those of other similar age, experience and background, to help in improving learning, Kleeman, (2013).

\section{Criterion-Referenced Assessment}

In this kind of exam, however, Kirylo \& Millet, (2015), state that the score would reflect how many more or fewer correct answers a student gave in comparison to other students. Criterion-referenced test results are often based on the number of correct answers provided by students, these scores might be expressed as a percentage of the total possible number of correct answers.

\section{Ipsative Assessment}

John Kleeman, (2013), states that the advantage of impassive assessment is that it measures progress and development a test taker can see if he or she is taking advantage of feedback from previous assessments, thus, teachers and students are able to identify progress which is being made.

\section{Benchmark Assessment}

Black \& William, (2008), define benchmark assessment as assessment administered periodically throughout the school year, at specified times during a curriculum sequence, to evaluate student's knowledge and skills relative to an explicit set of long- term learning goals. The design and choice of bench mark assessment is driven by the purpose, intended user and uses of the instruments. Kothari, (2013),view.benchmark assessment as test sad ministered throughout the school year that give teachers immediate feedback on how students are meeting academic standards. It is given during or after class activity to help teachers know whether students have understood the content that has been covered.

\section{Summative Assessment}

Kothari, (2013), affirms that summative assessment is used as a checkpoint at the end of the year or course to assess how much content student learned in overall and that it is similar to benchmark testing, but instead of only covering one unit, it cumulatively covers everything students have been spending time over a long period of time.

\section{METHODOLOGY}

\section{Study Area}

The study was conducted in public primary schools in Awendo sub-county, Awendo sub-county is in Migori County. It borders Rongo sub-county to the North, Homa Bay County to the West and Uriri sub-county to the East. It covers an area of 26190 square kilometres, (www.mudavadi2013.com) and a population of 108913, (National Census 2009). There are 73 public primary schools in the sub-county. 


\section{Research Design}

A descriptive research design utilizing qualitative and quantitative research methods was used because according to Frankel and Wallen, (2003), a descriptive survey research is a design that involves asking a group of people questions about their perceptions or attitudes towards a particular issue. It is a method of collecting information by interviewing or administering a questionnaire to a sample of individuals, (Orodho, 2003). It can be used when collecting information about people's attitudes, opinion, habits or any of the variety of education or social issues,

Orodho and Kombo, (2002). It was, therefore, considered appropriate because it allowed for both qualitative and quantitative analysis of data, resulting to a detailed study.

\section{Study Population}

The study focused on 71 public primary schools that used different types of assessment tests. This included 71 head teachers, 71 teachers of English, 5 curriculum support officers and 2354 pupils.

\section{Sample and Sampling Techniques}

Saturated sampling was used on 71 head teachers, 71 teachers of English and 5 curriculum support officers. However, simple random sampling was used to select 2354 pupils drawn from the entire sub-county.

\section{Instruments for data collection}

The main instruments that were used to collect data were questionnaires, interviews and document analysis. Data

\section{Collection Procedures}

The collection of data was carried out in three stages. The first stage concentrated on a review of relevant related literature on types of continuous assessment tests used in the teaching and learning of English language. The second phase dealt with administering questionnaires to teachers of English and pupils. The third phase was concerned with conducting face to face interview with head teachers and curriculum support officers.

\section{Findings}

The findings are shown in the table below:

Table 1: Teachers' Responses onTypesof Assessment Administered to Pupils

\begin{tabular}{|l|c|c|}
\hline Types of assessment & $\begin{array}{c}\text { Teachers of } \\
\text { English }\end{array}$ & Percentage \\
\hline Formative Assessment & 52 & $73.24 \%$ \\
\hline Summative Assessment & 19 & $26.76 \%$ \\
\hline Total & 71 & $100 \%$ \\
\hline
\end{tabular}

Table1 indicates that 52(73.24\%) teachers of English were using formative assessment in the teaching and learning of English language

Table 2: Pupils’ Responses on Types of Assessments

\begin{tabular}{|l|c|c|}
\hline \multicolumn{1}{|c|}{ Types of assessment } & Pupils & Percentage \\
\hline Formative assessment & 170 & $72.34 \%$ \\
\hline Summative assessment & 65 & $27.66 \%$ \\
\hline Total & 235 & $100 \%$ \\
\hline
\end{tabular}

In table 2, the majority of pupils, $170(72.34 \%)$ stated that teachers were using formative assessment in the teaching and learning of English language.

\section{Teachers' Academic qualification and experience with the use of different types of assessment}

Table 3 Academic qualification of Head teachers

\begin{tabular}{|l|c|c|}
\hline Educational Level & Head teachers & Percentage \\
\hline P1 & 12 & 17.65 \\
\hline Diploma & 30 & 44.12 \\
\hline Degree & 26 & 38.23 \\
\hline PGD & - & - \\
\hline Total & $\mathbf{6 8}$ & $\mathbf{1 0 0}$ \\
\hline
\end{tabular}

As can be seen in the table above, majority of head teachers had better grades, $30(44.12 \%)$ had diplomas and $26(38.23 \%)$ were degree holders. This was important because they were competent to teach and assess English language. The education level of head teachers was also important because it gave them knowledge experience in their areas of 
jurisdiction, hence, better leadership skills that results in improved instructional methodologies and assessment and even guiding teachers in other academic areas.

Use of formative assessment in the teaching and learning of English language

The interviewee (head teachers) reported that they were encouraged by the CSOs to ensure that formative assessment was used in teaching and learning English language in class seven in their schools. The interview with head teachers revealed that $30 \%$ of teachers of English used question and answer method during the lessons, 55\% teachers used written work after the conclusion of the lesson and $15 \%$ gave homework.

\section{Pupils' responses on types of assessment}

In another development pupils in class seven were asked to state the types of continuous assessment tests given to them. The responses of the pupils are displayed in table 4.9.

Table 4: Pupils' responses on types of Assessment used by teachers

\begin{tabular}{|l|c|c|}
\hline Types of assessment & Pupils & Percentage \\
\hline Formative & 164 & 69.79 \\
\hline Summative & 71 & 30.21 \\
\hline Total & 235 & 100 \\
\hline
\end{tabular}

Table 4showed that majority of the pupils stated that formative assessment was used and it was helping them to compare and compete among themselves after getting their results. Formative assessment was given, for example, after a lesson, unit, weekly or fortnightly and it made the learners realize their strengths and weaknesses for possible improvement in their performance in English language. This showed that formative assessment was being used by most teachers of English to help in improving instructional methods, hence improved teaching and learning. This was considered important as it gave the pupils opportunity to assess their understanding.

\subsubsection{Teachers Responses on types of assessment}

The teachers were asked to mention types of assessment tests they use in teaching and learning of English language in class seven in public primary schools in Awendo Sub-County. It was necessary to determine the types of continuous assessment tests in order to understand the best method depending on the teaching and learning out comes as can be seen in table 4.8 .

Table 5: Teachers' responses on types of Assessment

\begin{tabular}{|l|c|c|}
\hline Types of assessment & Teachers of English & Percentage \\
\hline Formative Assessment & 60 & 84.51 \\
\hline Summative Assessment & 11 & 15.49 \\
\hline Total & 71 & 100 \\
\hline
\end{tabular}

According to table $560(84.51 \%)$ of teachers use formative assessment, however, 11(15.49\%) of teachers were practicing summative assessment. These percentages, showed that most teachers use formative assessment than summative assessment. This is in line with Heritage and Herman (2009) who believed that formative assessment should be used systematically and continuously to gather evidence and provide feedback about learning while instruction is process.

\section{Head teachers' responses on types of continuous assessment teachers give to pupils}

The head teachers were asked the types of assessment teachers of English used in class seven in the teaching and learning q1of English language. $64(94.12 \%)$ head teachers were not certain on the types of assessment teachers of English in their schools used. However, 4 (5.88\%) head teachers who taught English in class seven stated that they were using a variety of methods, including asking oral questions as lessons progressed, giving written work and take home assignments, thus, formative assessment. The study established that the type of assessment used in various schools depended on availability of resources, as teachers and pupils' course books, adequate supplementary books, staffing position of the school, and the teaching/learning methods.

\section{Curriculum Support Officers' responses on types of assessment}

All the 5 CSOs were also interviewed and asked to state their views on types of CATs administered in class seven in teaching and learning of English language. Three out of the five CSOs reported that formative assessment is very essential as a means of evaluation that enables the teacher to either plan for remedial work, or plan a new lesson, unlike summative assessment which is normally administered to learners at the end of term or year hence do not give teachers and learners room for assessment of teaching and learning while instruction is in progress. They also noted that in most cases teachers used oral and take away CATs. They remarked, "When pupils are given take away assignments, it keeps them busy at home and encourages them to continue doing class work and thus helps them to improve in their learning."

The other two CSOs responded on the type of assessment that, 'both formative and summative assessments are necessary in the teaching and learning of English language because all are checking the understanding of the learners at certain levels. 


\section{Document analysis on types of assessment}

The researcher used document analysis to obtain more qualitative data required regarding the types of continuous assessment tests administered to pupils in class seven in teaching and learning English language. The findings revealed that $51(71.8 \%)$ schools had no clear records indicating the types of assessment used in teaching/learning and assessment of English language in class seven. 20 (28.2) schools had records showing that they used varied methods of assessment such as question and answer, written work or homework. This data obtained indicates that majority of head teachers were not aware of the instructional methodologies and assessment teachers were using in teaching and learning of English language in class seven in public primary schools in Awendo Sub-County. Besides, these head teachers reported that they conducted only mid-term and end term assessment to pupils of class seven in English language. This is contrary to Grange \& Reddy, (2008), who argues that learners' progress should be continuously monitored through CATs and in the final analysis there would be efforts by teachers to address low performance by varying instructional methodologies.

\section{The role of formative assessment in the teaching and learning of English language}

Most teachers believe that the role of formative assessment is to boost learning.

Kothari, (2013), states that formative assessment is a wide variety of methods teachers use to conduct in-process evaluation of students' comprehension, learning needs and academic progress during a lesson or course. Kothari, (2013), further asserts that formative assessment is used to gauge student's learning during the lesson and also used throughout a lesson to give students opportunity to demonstrate that they have understood the concept. Garrison and Ehrighaus, (2007), mention that formative assessment is any assessment made during the class year to improve the learning process and provides the information needed to adjust teaching and learning while they are happening, and also helps teachers in administering next steps during the learning process. Teachers believe that formative assessment is a variety of methods including the use of different types of assessment which include diagnostic assessment, normreferenced assessment, ipsative assessment and benchmark/interim assessment. All these are used by means of oral work, written work and diagnostic assessment.

\section{How teachers use different types of assessment}

It was found out that teachers used different types of assessment for drill, practice and test understanding. 57 of the teachers reported, "Yes I drill my students for them to be acquainted with exams, to be able to perform highly in external examinations." However, 14 teachers stated that they used the types of assessment as a pattern of teaching, not meant to drill for rote memorization. Besides, all the teachers reported that they used different types of assessment to break boredom and bring a variety in teaching, hence improved teaching and learning. This is summarized in table 5 .

Table 6: How teachers use different types of assessment

\begin{tabular}{|l|l|l|}
\hline Drill & 57 & 80.28 \\
\hline Pattern of teaching & 14 & 19.72 \\
\hline Total & $\mathbf{7 1}$ & $\mathbf{1 0 0}$ \\
\hline
\end{tabular}

Table 7: Teachers' views about the use of different types of assessment to motivate pupils

\begin{tabular}{|l|l|l|}
\hline Responses & Teachers & $\%$ \\
\hline Motivating & 60 & $84.51 \%$ \\
\hline Delays syllabus coverage & 11 & $15.49 \%$ \\
\hline Total & 100 & $100 \%$ \\
\hline
\end{tabular}

From table 7, it can be seen that 60 teachers of English out of 71, believe that assessment helps to motivate pupils, especially when different types are used to bring a variety in teaching there by reducing monotony in teaching. However, 11 teachers did not see the value of assessment, claiming that they waste time, hence delays syllabus coverage.

\section{CONCLUSION}

Different types of assessment were being used in Awendo sub-county.The introduction and use of assessment in schools is essential in the teaching and learning process. The study revealed that on average, schools mostly, used formative assessment. However, they also used summative assessmentoccasionallyto sum up a whole term's or year's content.Consequently, the overall findings indicated that in most of the schools, there was little improvement in English language.The participants agreed that if different types of assessment are used, pupils develop a sense of competition among themselves, thus are motivated to learn. Teachers reported that after assessment, students discussed the questions and tried to find out where they went wrong even before revision with the teacher.

\section{REFERENCES}

[1].Bransford,J. (2005). Formative Assessment. USA. National Research Council.Bromley and Irwin, (1999). Organizational Learning; a critical review. USA. Professional Publishing.

[2].Buttler \& Rodlger, (2007). Continuous Assessment Improved Academics. Ethiopia. Public University of Eastern Ethiopia. 
[3].Ehringaus, G. (2007). Formative and summative assessment. UK. Kasdi University.

[4].Fraenkel, J.R. and Wallen, N.E. (2015). Designing and Evaluating Research in Education. Education and Development Conference. USA. San Francisco State University.

[5].Fraser, W.J. (2016).Continuous Assessment as a component for the monitoring of educational activities. UK. Plan College of Education.

[6].Graeme L. W. \& Naidoo, J. (2004). Assessment is done through terminal and fortnightly Examinations in the schools. Kenya. Laikipia University.

[7].Jacobs, H.R. \& Gawe, (2017).Tests and examinations focused only on cognitive aspects. https://www.onlineexambuilder.com.

[8].John Kleeman, (2013), Summative Continuous Assessment. UK. Ourgla University.

[9].Kirylo, G. (2015). Practice of Continuous Assessments in primary schools. UK. UNESCO.

[10]. Kothari, C.R. (2004). Research Methodology: Methods and Techniques (2 ${ }^{\text {nd }}$ Eddition). Delhi: New Age International Publishers

[11]. Kothari, C.R. (2003). Research Design and Methodology. Delhi. Wiley Eastern Limited.

[12]. Mugenda,O. \& Mugenda, M. (2003). Sample size percentage of the target population. Nairobi. St. Paul's University.

[13]. Orodho,J.A. and Kombo, D.K. (2002). Designing and Evaluating Research. Nairobi. Kenyatta University Institute of Open Learning.

[14]. Quansah, K, B. (2005). Continuous assessment handbook. Accra. Ghana education service.

[15]. Rodger Pierangelo, (2003), The Special Education Book of Lists. San Francisco. USA. Josse Bass.

[16]. Sarosdy, J. \& Bence, T, F. Vadnay, M. (2006). Applied linguistics 1 for BA students in English. Cambrige: Cambrige University Press.

[17]. Webb, N. \& Briars, D. (2010). Assessment as an interaction between the teacher and the students. Australia. Perspective on Mathematics.

[18]. Yoloye, E.A. (2008). Continuous Assessment. World Education Report. Paris. UNESCO- University of Ibadan.

[19]. Ysseldyke, J.K. (1998). Educational Tests and Measurements. Houghton. Mifflin 